\title{
Details in the China-Taiwan Free Trade Agreement
}

\author{
Kuo-I Chang \\ National Chung-Hsing University, Taichung, Taiwan \\ Kazunobu Hayakawa \\ Institute of Developing Economies, Bangkok, Thailand
}

\begin{abstract}
We conducted an empirical investigation into the determinants of Free Trade Agreement utilization in exports from Taiwan to China. First, we estimated the selection equation to see what kinds of products are included in the early harvest list. As a result, we found that Taiwan includes products with a medium magnitude of benefits from tariff removal in the early harvest list. We then estimated the equation for the determinants of Free Trade Agreement utilization by introducing an inverse of the Mills ratio estimated in the selection equation. As expected, the findings show that the Free Trade Agreement rates are more likely to be utilized for products with a larger tariff margin. In addition, some rules of origin are found to be relatively restrictive.
\end{abstract}

\footnotetext{
* Corresponding Author: Kuo-I Chang; Department of Applied Economics, National Chung-Hsing University, No.250, Guoguang Rd., South Dist., Taichung 402, Taiwan; Tel: +886 422850501, Fax: +886 422850501, E-mail: kic@nchu.edu.tw.

Co-Author: Kazunobu Hayakawa; Japan External Trade Organization, 16th Fl., Nantawan Building, 161 Rajdamri Road, Patumwan, Bangkok 10330, Thailand; Tel: +66 22536441, Fax: +66 22541447, E-mail: kazunobu_hayakawa@, ide-jetro.org.

Acknowledgements: This research was conducted as part of a project of the Japan External Trade Organization "Cause and Consequence of Firms' FTA Utilization in Asia." We are grateful to the Ministry of Economic Affairs, R.O.C. for providing us with the data used in this study. We also thank an anonymous referee, Jin-Long Liu, I-Hui Cheng, ShaoHusn Keng, Sheng-Jang Sheu, Da-Nian Liu, and seminar participants at the Chung-Hua Institution for Economic Research, National Central University, and the National University of Kaohsiung for their helpful comments.
} 
JEL Classification: F15, F23

Keywords: FTA, Utilization, China

\section{Introduction}

The Economic Cooperation Framework Agreement (ECFA) between Taiwan and China was signed on 29 June 2010. The scope of the agreement includes reducing tariffs, eliminating non-tariff trade barriers, promoting trade and investment contacts, and boosting economic development and employment. Previously, Taiwan had concluded FTAs with only a number of small Central American countries, mainly for political rather than economic reasons (Dent 2009). On the other hand, the ECFA seems to be motivated by economic reasons, at least compared with Taiwan's other FTAs. The crucial event was the conclusion of the ASEAN-China Free Trade Area (ACFTA). The Agreement on Trade in Goods was signed in 2004 and implemented on 1 July 2005 by the ASEAN countries and on 20 July 2005 by China. Under this agreement, the six original ASEAN members and China were obliged to eliminate tariffs on $90 \%$ of their products by 2010, while Cambodia, Lao PDR, Myanmar, and Vietnam have until 2015 to do so. As a result, the majority of exports from ASEAN countries to China enjoy the lower tariff rates. Since Taiwanese firms have competed in the China market with firms from a number of ASEAN countries, Taiwanese companies were anxious about their position regarding market access. Taiwan therefore concluded the ECFA with China in order to resolve this disadvantage in the China market (Chen et al. 2011).

The purpose of this paper is twofold. The first is to investigate empirically how early harvest products are selected. As of 2011, regarding tariff removal, the ECFA simply began tariff reduction on products listed in the early harvest program. Under the program, China implemented tariff reductions on 539 items originating from the Taiwan region, including agricultural products, chemical products, mechanical products, electronic products, automobile parts, textile products, light industrial products, metallurgical products, instrumental products, and medical products. ${ }^{1}$ In this paper, we investigate empirically how these 539 products were selected. The second purpose is to

\footnotetext{
Tariff reduction by the Taiwan region was carried out for 268 products in four categories originating in China, including petroleum chemicals, mechanical products, and textile products, among others.
} 
explore for what kinds of products among the selected 539, higher utilization of FTA preferential rates can be seen. Specifically, we examine the roles of the margin between general tariff rates and FTA preferential rates and the restrictiveness of Rules Of Origin (ROOs). As conceptualized in the following sections, these two types of elements are major determinants of FTA utilization.

This paper contributes to the literature in at least three ways. First, our analysis on the selection of products with preferential rates is related to studies in the literature of endogenous tariff/protection formation. This literature is extremely large and examines how industrial tariff/protection is determined. The major references include Ball (1967), Stigler (1971), Pincus (1975), Caves (1976), Hillman (1982), Mayer (1984), Grossman and Helpman (1994, 1995), Cadot et al. (1997), Mitra (1999), Gawande et al. (2006), and Bombardini (2008). Specifically, these studies have shed light on industrial characteristics including the extent of industry concentration, the magnitude of import penetration, production processes, capital-labor ratio, the prevalence of intra-industry trade, the level of wages, the significance of employment size, trade creation, and the distribution of firm productivity (Olarreaga and Soloaga 1998). While controlling for such industry-specific elements by introducing industry dummy variables, we focus on product-specific elements. In particular, as mentioned above, our interest lies in whether or not the ECFA early harvest products are more likely to be chosen among products with the larger margin between general rates and ACFTA rates. This hypothesis is similar to the finding of Estevadeordal, Freund, and Ornelas (2008); Most Favored Nation (MFN) rates are likely to be lower in the case of products with the lower preferential rates. However, our paper differs in terms of examining how one type of preferential tariff rates depends on another type of preferential rates.

The second contribution, which is related to the first, is that we take into account the selection of products with FTA preferential rates in our analysis on FTA utilization. There are several papers analyzing the determinants of FTA or Generalized Scheme of Preferences (GSP) utilization: Bureau et al. (2007), Cadot et al. (2006), Francois et al. (2006), Hakobyan (2010), and Manchin (2006). The elements examined in the determinants of FTA utilization are almost identical across all papers, including the margin between general tariff rates and preferential tariff rates, size of trade, restrictiveness of ROOs. Thus, similar results are obtained in the literature; for example, FTA utilization rates are higher in products with a larger tariff margin. While all of the previous studies take a list of products with FTA rates as given, the products with the FTA preferential rates should be systematically selected. In particular, as mentioned 
above, the tariff reduction started from a very limited number of products in the case of the ECFA. Those products seem to have been selected on the basis of several different motivations on the part of China and Taiwan. For example, Taiwan attempted to include products for which tariff elimination is expected to yield larger benefits in the early harvest list. Like ECFA, almost all FTAs available in the world exclude some products, particularly products in the so-called exclusion list, from the list of products for which tariff reduction is implemented. Thus, due to restricting sample products only to the products with FTA rates, the estimators in the previous studies will have suffered from the well-known sample selection bias. In this paper, we tackle this sample selection bias by employing the Heckman estimation technique. Namely, we first estimate the equation for the kinds of products that obtain FTA preferential treatment. Secondly, we estimate the equation for the determinants of FTA utilization by introducing an inverse of the Mills ratio estimated in the selection equation. Consequently, our estimators show the consistent ones in the determinants of ECFA utilization.

Our third contribution is one that is specific to studies on ECFA. This is the first paper in terms of evaluating the ECFA using the ex-post data. So far, there are few previous studies on the ECFA (Chen et al. 2009, Hong and Yang 2011). These studies conducted an ex-ante evaluation of the ECFA by simulating the well-known Global Trade Analysis Project model. This paper, on the other hand, attempts to evaluate, to some extent, how effectively the ECFA is used by employing data on how much ECFA is used. This analysis is important, particularly in the context of the ECFA, because the two parties have not yet even begun negotiations on tariff removal beyond the early harvest program. That is, the results of our analysis contribute to predicting how effectively the normal/sensitive track of the ECFA will work in the future.

The remainder of this paper is organized as follows. The following section is an overview of the ECFA. Section III provides our empirical framework for examining the determinants of ECFA utilization. After taking a look at ECFA utilization in Section IV, we present our estimation results in Section V. Lastly, Section VI concludes this paper.

\section{Economic Cooperation Framework Agreement}

This section introduces the method for tariff removal in the ECFA early harvest 
products, the preferential level of ECFA tariff rates, and the rules of origin in the ECFA. First, the tariff removal method in the ECFA is systematically determined based on the level of MFN rates in 2009. The three types of tariff removal schedule for the ECFA in China are as follows: (i) tariff rates on products with MFN rates from $0 \%$ to $5 \%$ in 2009 decrease to $0 \%$ in the first year (2011); (ii) tariff rates on products with MFN rates from $5 \%$ to $15 \%$ in 2009 decrease to $5 \%$ in the first year (2011) and $0 \%$ in the second year (2012); and (iii) tariff rates on products with MFN rates higher than $15 \%$ in 2009 decrease to $10 \%$ in the first year (2011), 5\% in the second year (2012), and $0 \%$ in the third year (2013). In short, tariff removal for the ECFA early harvest products will be completed in the year 2013.

Table 1. ECFA tariff schedule for Taiwanese exports to China

\begin{tabular}{|c|c|c|c|c|}
\hline Type & MFN rates in 2009 $\mathbf{( X \% )}$ & 1st Year & 2nd Year & 3rd Year \\
\hline (i) & $0<\mathrm{X} \leq 5$ & 0 & & \\
\hline (ii) & $5<\mathrm{X} \leq 15$ & 5 & 0 & \\
\hline (iii) & $\mathrm{X}>15$ & 10 & 5 & 0 \\
\hline
\end{tabular}

(Source) Legal text of Economic Cooperation Framework Agreement.

How preferential are the ECFA tariff rates? To answer this question, we compare the ECFA rates with the tariff rates in other FTAs. In particular, we shed light on the preferential tariff rates on China's imports from Korea and ASEAN countries since those countries are the main competitors of Taiwanese firms in the China market. Korea enjoys preferential tariff rates based on the Asia-Pacific Trade Agreement (APTA), signed in 1975 as an initiative of the United Nations Economic and Social Commission for Asia and the Pacific (ESCAP). APTA is a preferential tariff arrangement that aims at promoting intra-regional trade through exchange of mutually agreed concessions by the member countries of Bangladesh, China, India, Korea, Lao PDR, and Sri Lanka. ASEAN countries enjoy preferential status in the China market due to the conclusion of ACFTA. ECFA, APTA, and ACFTA preferential tariff data for China are drawn 
from the official ECFA website, ${ }^{2}$ China Customs Law Firm online, ${ }^{3}$ and China FTA Network online, ${ }^{4}$ respectively. We also refer to the World Integrated Trade Solution tariff database, ${ }^{5}$ ACFTA knowledge handbook, ${ }^{6}$ and MFN rates adjustment tables of the Department of Finance, Ministry of Commerce of the People's Republic of China.

Table 2 shows a comparison of ECFA rates with China's MFN rates, APTA rates for Korea, and ACFTA rates in 2011, 2012, and 2013. We find that, in 2011, 77\% of the ECFA products have less than a 5\% tariff margin between ECFA and MFN rates. In particular, due to the reduction of MFN rates, there is already no margin for six products. However, from 2012, most of the ECFA products have more than a 5\% margin. The literature estimates the FTA compliance costs to be around 5\% (Cadot and de Melo 2007, Hayakawa 2011). In other words, firms tend to use FTA schemes if the tariff margin between FTA and MFN rates is higher than 5\%. Thus, ECFA rates might be more frequently used from 2012. Second, in 2011, 93\% of the ECFA products already had lower tariff rates than APTA products. Third, $84 \%$ of the ECFA products still had higher tariff rates than ACFTA products in 2011. Most of the ECFA products have higher tariff rates than ACFTA products, implying that ECFA rates in 2011 were not low enough to compete with ASEAN countries in terms of preferential access. The ECFA rates have become as competitive as ACFTA rates from 2012.

\footnotetext{
${ }^{2}$ Official ECFA website: www.ecfa.org.tw (accessed on 15 September 2010)

${ }^{3}$ http://www.customslawyer.cn/hgsz/ShowArticle.asp?ArticleID=44116

${ }^{4} \mathrm{http}: / / \mathrm{fta} \cdot \mathrm{mofcom} . \mathrm{gov} . \mathrm{cn} /$

${ }^{5}$ http://wits.worldbank.org/wits/

${ }^{6}$ http://gjs.mofcom.gov.cn/table/acfta_manual.pdf

${ }^{7}$ http://cws.mofcom.gov.cn/
} 
Table 2. Comparison of ECFA rates

\begin{tabular}{|c|c|c|c|c|c|c|}
\hline & \multicolumn{2}{|c|}{2011} & \multicolumn{2}{|c|}{2012} & \multicolumn{2}{|c|}{2013} \\
\hline & Tariff line & Share & Tariff line & Share & Tariff line & Share \\
\hline \multicolumn{7}{|c|}{ Comparison with MFN rates } \\
\hline Margin $=0$ & 6 & $1 \%$ & 6 & $1 \%$ & 6 & $1 \%$ \\
\hline $0<$ Margin $\leq 5$ & 411 & $76 \%$ & 72 & $13 \%$ & 72 & $13 \%$ \\
\hline $5<$ Margin $\leq 10$ & 114 & $21 \%$ & 339 & $63 \%$ & 337 & $63 \%$ \\
\hline Margin $>10$ & 8 & $1 \%$ & 122 & $23 \%$ & 124 & $23 \%$ \\
\hline \multicolumn{7}{|c|}{ Comparison with APTA rates to Korea } \\
\hline ECFA $<$ Korea & 502 & $93 \%$ & 532 & $99 \%$ & $532 \%$ & $99 \%$ \\
\hline $\mathrm{ECFA}=$ Korea & 8 & $1 \%$ & 6 & $1 \%$ & $7 \%$ & $1 \%$ \\
\hline ECFA $>$ Korea & 29 & $5 \%$ & 1 & $0 \%$ & $0 \%$ & $0 \%$ \\
\hline \multicolumn{7}{|c|}{ Comparison with ACFTA rates } \\
\hline $\mathrm{ECFA}<\mathrm{ASEAN}$ & 11 & $2 \%$ & 16 & $3 \%$ & 19 & $4 \%$ \\
\hline $\mathrm{ECFA}=\mathrm{ASEAN}$ & 77 & $14 \%$ & 496 & $92 \%$ & 520 & $96 \%$ \\
\hline $\mathrm{ECFA}>\mathrm{ASEAN}$ & 451 & $84 \%$ & 27 & $5 \%$ & 0 & $0 \%$ \\
\hline
\end{tabular}

(Sources) Official ECFA website, China Customs Law Firm online, China FTA Network online, World Integrated Trade Solution tariff database, ACFTA knowledge handbook, and MFN rates adjustment tables of the Department of Finance, Ministry of Commerce of the People's Republic of China.

Figure 1 shows the $10 \mathrm{ROO}$ types in ECFA. CS, CH, and $\mathrm{CC}$ are the $\mathrm{ROO}$ criteria of Change in Subheading, Change in Heading, and Change in Chapter, respectively. ${ }^{8}$ WO indicates the Wholly Obtained criterion. ${ }^{9} \mathrm{RVCL}$ and $\mathrm{RVCH}$ are the ROO criteria for the less than $40 \%$ real value-added and the greater than $40 \%$ real value-added, respectively. ${ }^{10}$ Roughly speaking, severity increases in the order of $\mathrm{CS}, \mathrm{CH}, \mathrm{CC}, \mathrm{RVCL}, \mathrm{RVCH}$, and WO. Furthermore, when these are combined by AND, severity increases, and becomes

\footnotetext{
${ }^{8}$ For example, Change in Subheading requires non-originating inputs for producing exported products to have different harmonized system (HS) 6-digit codes from exported products. Similarly, in the cases of Change in Heading and Change in Chapter, non-originating inputs must have different HS 4-digit and 2-digit codes from exported products, respectively.

${ }^{9}$ Wholly obtained criterion requires exported products to be wholly obtained or produced entirely in exporting countries.

${ }^{10}$ In the case of $\mathrm{X} \%$ real value-added rules, for example, total real value added of originating inputs must have at least $\mathrm{X} \%$ of exported products' prices.
} 
looser when combined by OR. We find that around 75\% of the ECFA products have Change in Heading or Change in Chapter as rules of origin, and around $20 \%$ of the ECFA products have AND-type rules of origin, namely CS\&RVCH, CH\&RVCL, CH\&RVCH, and CC\&RVCL. Thus, in the case of ECFA, ROOs may not have seriously negative impacts on the use of ECFA tariff schemes.

\section{Figure 1. Rules of origin types in economic cooperation framework agreement}

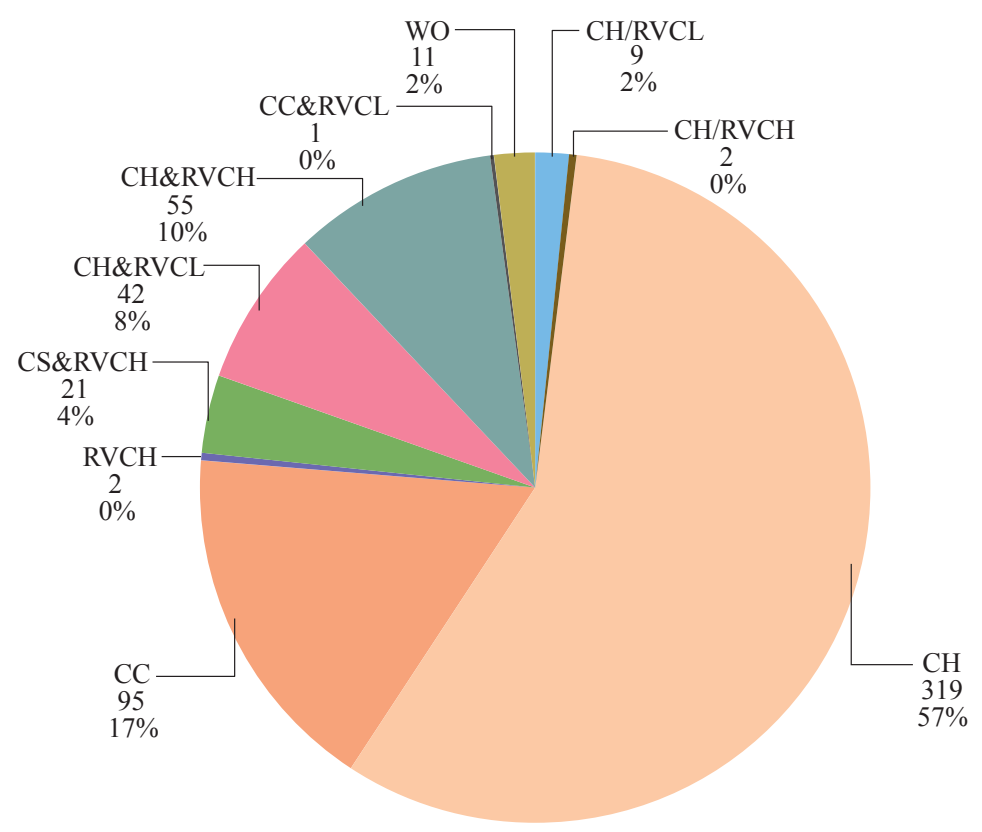

(Notes) $\mathrm{CS}, \mathrm{CH}$, and $\mathrm{CC}$ are the $\mathrm{ROO}$ criteria of Change in Subheading, Change in Heading, and Change in Chapter, respectively. WO indicates the Wholly obtained criterion. RVCL and RVCH are the ROO criteria for the less than $40 \%$ real value-added and the greater than $40 \%$ real value-added, respectively.

(Source) Legal text of Economic Cooperation Framework Agreement.

\section{Empirical Design}

As mentioned in the introductory section, we employ the Heckman estimation technique. Namely, we first estimate the equation for the kinds of products that obtain 
FTA preferential treatment. We call such products FTA products. Thus, our first step estimates the equation for the selection on FTA products. ${ }^{11}$ We then estimate the equation for FTA utilization by introducing an inverse of the Mills ratio estimated in the selection equation. In this section, we first specify the selection equation and then the equation for FTA utilization.

\section{A. Selection of FTA products}

Here, we specify the selection equation for FTA products. For this, the literature of endogenous tariff/protection formation is helpful. In this literature, studies explore how the level of protection in an industry is determined. In this paper, while controlling the industry-specific elements by introducing industry dummy variables, we focus on product-specific elements. Specifically, our selection equation is formalized as follows:

$\operatorname{Prob}\left(F T A\right.$ Products $\left._{p}(t)=1 \mid X\right)=\beta_{0}+\beta_{1}\left(\operatorname{MFN}_{p}(t-1)\right)+\beta_{2}$ Taiwanese Exports China $(t-1)+\beta_{3}\left(\operatorname{MFN}_{p}(t-1)-\right.$ ACFTA $\left._{p}(t-1)\right)+\beta_{4}$ Chinese RCA $(t-1)+\beta_{5}$ Taiwanese RCA $(t-1)+\beta_{6}$ Intra-industry Trade $_{p}(t-1)+u_{i}+\eta_{p}(t)$

The dependent variable, FTA Products, $s_{p}$, is an indicator variable taking unity if product $p$ is included in the early harvest list and zero otherwise. All explanatory variables take values existing in the year before the ECFA's entry into force. $u_{i}$ is the industry dummy variable defined at the section-level of Harmonized System (HS) tariff classification as shown in Table 3. As mentioned later, our second stage estimation is conducted at HS 6-digit level. Thus, we also use the 6-digit level variables in the selection equation. The dependent variable takes unity if any of the products within the same classification at the 6-digit level are listed in the early harvest products and zero otherwise.

Our product-specific explanatory variables are as follows. We first introduce China's

\footnotetext{
${ }^{11}$ FTA preferential products, FTA preferential rates, and rules of origin will be simultaneously determined during the negotiations. In our analysis, we only take the selection of FTA preferential products into account

${ }^{12}$ One may say that the estimates suffer from serious biases if 9-digit products are included in the early harvest program, and occupy only a minor share in a HS 6-digit code. In order to check this possibility, this study calculated the share of exports of FTA products in 2009 , according to HS 6-digit codes, and found that only $3 \%$ of HS 6-digit codes with at least one FTA product have the minor share (less than $50 \%$ ). Indeed, in more than $90 \%$ of HS 6-digit codes with at least one FTA product, the share of exports of FTA products rises above $80 \%$. Thus, it is believed that the above-mentioned biases are trivial.
} 
MFN rates on Taiwanese products, $M F N_{p}(t-1)$. From the theoretical point of view, Taiwan will try to include the products for which tariff elimination is expected to yield larger benefits in the early harvest list. As discussed in the next subsection, such larger benefits can be expected for products with higher general rates, namely MFN rates. In order to examine this hypothesis, we introduce China's MFN rates on Taiwanese products. Also, since products with zero MFN rates are not on the table of negotiations, such products are excluded from our sample.

Second, we examine the role of the past magnitude of exports from Taiwan to China, which is denoted by Taiwanese Exports China $a_{p}(t-1)$. If exporting countries try to open the market for more protected products, products with the smaller volume of exports may be selected as FTA products. On the other hand, if imports of a product were large before FTA conclusion, their further increase due to tariff reduction through FTAs may yield a less drastic industrial adjustment in the market in importing countries. In short, importing countries may more easily accept the inclusion in FTA products of products whose import volume is already large. As a result, many forces are at work, and the net result would depend upon the relative strength of these forces.

Third, we introduce the tariff margin between ACFTA rates and MFN rates in China, which is our main variable in this equation. Taiwan, so as not to be disadvantaged against ASEAN countries in terms of tariff rates, may attempt to include in the early harvest list, products with large tariff margins in ACFTA. China is also more likely to accept the granting of preferential treatment for products that are already included in other FTAs. As found in Table 2, since APTA rates for Korea are not so different from those of MFN, we do not examine the margin between APTA rates and MFN rates.

Fourth, we include China's and Taiwan's competitiveness measures. On the one hand, trade liberalization regarding products for which China has competitiveness in producing will not yield a drastic increase in Taiwanese exports of those products. Namely, China may more easily accept the inclusion of such products into the early harvest list. On the other hand, Taiwan must try to include products for which Taiwan has competitiveness in producing. In order to examine these effects, we introduce the revealed comparative advantage indices for China and Taiwan. Specifically, for example, China's index is calculated as [(Chinese exports of product $p$ to the world/Chinese total exports to the world)/(World exports of product $p$ /World total exports)]. Since the larger index means a larger comparative advantage, it is expected that both variables will have positive coefficients.

Lastly, the extent of intra-industry trade is examined. As Levy (1997) argues, while 
an increase in intra-industry trade benefits all agents, an increase in inter-industry trade has the usual Stolper-Samuelson redistributive effects and thus yields more serious conflict. Therefore, products with a larger extent of intra-industry trade will be more likely to be selected because of the easier acceptance by firms producing such products. Following Olarreaga and Soloaga (1998), we measure the extent of intra-industry trade using [(Taiwanese imports from China-Taiwanese exports to China $)^{2} /($ Taiwanese imports from China + Taiwanese exports to China) $\left.)^{2}\right]^{0.5}$.

Our data sources for this analysis are as follows. The information on tariff rates is the same as in the previous section. The tariff variables are calculated at the 6-digit level by taking their 6-digit level simple average among products at the tariff line level. The other variables on trade structure are calculated by employing the 6-digit level trade data. All trade data are obtained from the World Trade Atlas (Global Trade Information Services). Chinese and Taiwanese RCA indicators are calculated using the trade data of the respective countries, these data also being drawn from the World Trade Atlas. We set times $t$ and $t^{-1}$ as 2011 and 2009, respectively since the method for tariff removal in the ECFA is negotiated and is systematically determined based on the level of MFN rates in 2009.

\section{B. FTA utilization}

Our conceptual framework on firms' FTA utilization is as follows. As explored in previous studies, the use of FTA schemes is dependent upon their benefit and cost. The major benefit is that firms can save the tariff payment when exporting. If firms choose to use an FTA scheme, then they can export their products using the FTA preferential tariff rates. Otherwise, they must pay the general tariff rates, which are mostly MFN rates. Therefore, a larger difference between FTA rates and MFN rates leads to a larger amount of tariff payment saving. In other words, the larger the tariff margin, the more likely the firms are to use FTA schemes.

On the other hand, the cost of FTA utilization is the procurement adjustment cost. For the use of an FTA scheme, firms need to secure the ROOs of their product, which are the criteria for determining the origin of goods. Compliance with the ROO requirement may force firms to change procurement origins, which would raise their procurement costs, since the original procurement arrangements should have been optimal. Thus the unit cost in the case of FTA is as high as or higher than that in the case of general rates. The 
difference in unit costs will depend on how restrictive the ROOs are for firms. In other words, the less restrictive the ROOs, the more likely the firms are to use FTA schemes for their exports.

In sum, the crucial elements for firms' FTA utilization are the magnitude of tariff margin and the restrictiveness of ROOs. In order to examine these elements empirically, we estimate the following equation ${ }^{13}$ :

$$
\ln \left[F T A \operatorname{Users}_{p}(t)\right]=\beta_{0}+\beta_{1} \ln \left(\operatorname{MFN}_{p}(t)-\operatorname{ECFA}_{p}(t)\right)+R O O_{p}(t) \gamma+u_{i}+\varepsilon_{p}(t)
$$

$F T A$ Users $_{p}$ is the number of firms using FTA schemes in product $p . M F N_{p}$ and $E C F A_{p}$ are MFN rates and ECFA preferential rates, respectively. $R O O_{p}$ is a vector of dummy variables regarding ROO types, which are listed in the previous section. We also include the industry dummy variable. The coefficient for tariff margin $\left(\beta_{1}\right)$ is expected to be significantly positive. A vector of coefficients for ROO dummy variables $(\gamma)$ is expected to show how differently each ROO type affects FTA utilization. A more restrictive ROO type will have a larger negative coefficient.

Our data sources for this analysis are as follows. The source of MFN and ECFA rates is the same as in the previous section. The type of ROO in each product can be identified in the legal text of the ECFA. In this paper, due to the data limitation, the magnitude of FTA utilization is captured by the number of ECFA users, not trade values under the ECFA schemes. More specifically, FTA Users is defined as the number of Certificates Of Origin (COOs) divided by exports. From the Ministry of Economic Affairs in Taiwan, we were only able to obtain data on the number of COOs issued for Taiwanese preferential exports to China. Although this is a serious data disadvantage compared with the previous studies, we later attempt to minimize the qualitative differences in the measure of FTA utilization. ${ }^{14}$ In order to normalize those numbers among products, we divide by exports. Also, since our data on the number of COOs are those at the HS 6-digit level, the unit of our empirical analysis is, of necessity, the HS 6-digit level. The exports used for the above-mentioned normalization are calculated so as to exclude those for products not listed in the early harvest program by employing trade data at the tariff line level (9-digit level). The tariff margin is calculated at the 6-digit level by taking its 6-digit level simple average among products at the tariff line level. Fortunately, there

\footnotetext{
${ }^{13}$ Following the previous studies, we take a log of variables. However, the results would be qualitatively unchanged even if nonlogged variables had been used.

${ }^{14}$ Furthermore, after obtaining COOs, exporters may end up not exporting or not claiming the program at the border.
} 
are no differences in ROOs among products at the 9-digit level within the same 6-digit classification.

\section{Overview of Economic Cooperation Framework Agreement Utilization}

In this section, we take a brief look at how much the ECFA rates are utilized and how much the ECFA increases the Taiwanese exports to China. Table 3 reports utilization of FTAs in Taiwanese exports in 2011. The COO divided by exports is taken as the normalized number of FTA users. We find that the number of COOs issued is large in Plastics and rubber and Machinery. In particular, taking the number of tariff lines with FTA rates into account, we can say that the number of COO in Plastics and rubber is outstanding. Normalizing it by dividing with exports, we can see a very high rate of utilization in Leather products. However, it is obvious that this measure of FTA utilization depends on a number of factors. For example, an industry in which trade values per unit are generally larger will have larger exports, resulting in the lower normalized numbers. Namely, the differences in our utilization measures among industries are based not only on the utilization of the FTA but also on industry characteristics. 
Table 3. Utilization of FTAs in Taiwanese exports

\begin{tabular}{|l|c|c|c|}
\hline & Tariff lines & Certificates Of Origin & Utilization \\
\hline Live animals & 5 & 647 & 72 \\
\hline Vegetable products & 11 & 416 & 138 \\
\hline Mineral products & 4 & 177 & 0.4 \\
\hline Chemical products & 47 & 3,876 & 4 \\
\hline Plastics and rubber & 50 & 12,581 & 5 \\
\hline Leather products & 3 & 13 & 1,411 \\
\hline Textiles & 115 & 5,893 & 15 \\
\hline Footwear & 3 & 6 & 0.2 \\
\hline Pottery & 6 & 170 & 11 \\
\hline Base metal & 61 & 5,439 & 5 \\
\hline Machinery & 110 & 13,563 & 6 \\
\hline Transport equipment & 13 & 5,406 & 21 \\
\hline Precision machiinery & 5 & 422 & 4 \\
\hline Miscellaneous & 4 & 178 & 3 \\
\hline
\end{tabular}

(Notes) This table reports figures for 2011. Tariff lines indicates the number of tariff lines with ECFA preferential tariff rates. Certificates of Origin is the number of COOs issued. Utilization is COO divided by exports (million US dollars).

(Sources) Ministry of Economic Affairs (Taiwan), World Trade Atlas (Global Trade Information Services).

As mentioned in the previous section, we expect a more frequent use of ECFA rates for products with larger tariff margins. If this is correct, we may be able to see a more drastic increase in Taiwanese exports for such products. Table 4 shows the changes in Taiwanese exports to China from 2009 to 2011. Margin is the difference between ECFA rates and MFN rates for China. On average, ECFA products do not experience a greater increase of exports to China than non-ECFA products. In this sense, it is unclear whether or not ECFA contributes to a boosting of trade from Taiwan to China. However, 
consistent with our expectation, a greater increase of exports to China can be seen in ECFA products with a larger tariff margin. The products with small, medium, and large margins have experienced export increases of $36 \%, 89 \%$, and $96 \%$, respectively.

Table 4. Changes in Taiwanese exports to China

(unit of measure: million US dollars)

\begin{tabular}{|c|c|c|c|}
\hline & $\mathbf{2 0 0 9}$ & $\mathbf{2 0 1 1}$ & Change \\
\hline Without ECFA rates & 71,873 & 105,448 & $47 \%$ \\
\hline With ECFA rates & 13,833 & 19,448 & $41 \%$ \\
\hline $0<$ Margin $\leq 5$ & 12,676 & 17,265 & $36 \%$ \\
\hline $5<$ Margin $\leq 10$ & 1,140 & 2,150 & $89 \%$ \\
\hline Margin $>10$ & 17 & 33 & $96 \%$ \\
\hline
\end{tabular}

(Notes) Margin is the difference between ECFA rates and MFN rates for China.

\section{Empirical Results}

In this section, we report our estimation results on the equations specified in the previous section. We first provide the results for the selection equation, Equation (1), and then those for FTA utilization, Equation (2). Robustness checks are also conducted.

\section{A. Results for the selection of FTA products}

The results for the selection equation are reported in column (I) in Table 5. There are four points that are noteworthy. (i) The coefficient for MFN is estimated to be insignificant. This result is inconsistent with our hypothesis that Taiwan includes products with larger potential benefits from tariff removal in the early harvest list. (ii) Based on the significantly positive coefficient for Taiwanese exports to China, we can say that importing countries easily accept the inclusion of products that they have already 
been importing in substantial amounts. (iii) Tariff margin in ACFTA, Chinese RCA, and Taiwanese RCA have insignificant coefficients. Thus, contrary to the public view, the early harvest list in ECFA was completed independently from ACFTA rates. (iv) The coefficient for intra-industry trade is estimated to be significantly positive, indicating that products with a larger extent of intra-industry trade are more likely to be selected, possibly due to easier acceptance by firms in the same industry.

Table 5. Probit results of selection equation

(Marginal Effect)

\begin{tabular}{|l|c|c|}
\hline & (I) & (II) \\
\hline MFN $(t-1)$ & 0.024 & \\
\hline Dummy $[0.05<M F N(t-1) \leq 0.15]$ & {$[0.044]$} & $0.009 * *$ \\
& & {$[0.004]$} \\
\hline Dummy $[M F N(t-1)>0.15]$ & & 0.00003 \\
& & {$[0.009]$} \\
\hline Taiwanese Exports to China $(t-1)$ & $0.010^{* * *}$ & $0.010^{* * *}$ \\
& {$[0.001]$} & {$[0.001]$} \\
\hline Tariff Margin in ACFTA $(t-1)$ & 0.020 & 0.038 \\
& {$[0.060]$} & {$[0.062]$} \\
\hline Chinese RCA $(t$-1 $)$ & 0.0003 & 0.0002 \\
& {$[0.0004]$} & {$[0.0005]$} \\
\hline Taiwanese RCA $(t-1)$ & -0.0002 & -0.0002 \\
& {$[0.0004]$} & {$[0.0004]$} \\
\hline Intra-industry Trade $(t-1)$ & $0.011^{* * *}$ & $0.011 * *$ \\
& {$[0.005]$} & {$[0.005]$} \\
\hline Number of observations & 4,244 & 4,244 \\
\hline Pseudo log-likelihood & -994 & -990 \\
\hline Pseudo R ${ }^{2}$ & 0.2777 & 0.2806 \\
\hline
\end{tabular}

(Notes) (i) The dependent variable is an indicator variable taking unity if a product is listed as an early-harvest product in ECFA and zero otherwise.

(ii) The parentheses are robust standard errors.

(iii) $* * *, * *$, and $*$ show $1 \%, 5 \%$, and $10 \%$ significance, respectively.

(iv) Industry dummy variables are included in all estimations. 
As mentioned in Section II, ECFA rates are systematically determined according to the level of MFN rates in 2009. In particular, 5\% and 15\% play the role of cutoffs in determining the magnitude of tariff reduction in the ECFA. Therefore, whether products have MFN rates greater than $5 \%$ or $15 \%$ may be important in selecting FTA products. To examine the role of such cutoffs, instead of $M F N_{p}(t-1)$, the following two dummy variables are introduced: Dummy $\left[0.05<\operatorname{MFN}_{p}(t-1) \leq 0.15\right]$ is a dummy variable taking one if MFN rates for product $p$ range from $5 \%$ to $15 \%$ (medium MFN rates) and zero otherwise. Dummy $\left[M F N_{p}(t-1)>0.15\right]$ takes one if MFN rates for product $p$ are greater than $15 \%$ (high MFN rates) and zero otherwise. The results are reported in column (II) in Table 5. Interestingly, while the coefficient for the medium MFN rates is estimated to be significantly positive, that for the high MFN rates is insignificantly negative. These results may indicate that China accepts the inclusion of products with a medium magnitude of benefits from tariff removal, but avoids the inclusion of products with a large magnitude of benefits. The other variables have qualitatively the same results as in column (I).

\section{B. Results for FTA utilization}

Next, the results on FTA utilization, Equation (2), are reported in Table 7. Columns (I) and (II) show the Ordinary Least Squares (OLS) results with and without the Mills ratio, which is obtained from the results in Table 5. In particular, based on the improvement of Pseudo log-likelihood and Pseudo R-squared, we use the Mills ratio as calculated based on the results in column (II) in Table 5. Furthermore, in order to take a log of dependent variables, we drop observations with no FTA users, that is, no certificates of origins, from the sample. As a result, in Table 6 , we can see a significantly positive result in the Mills ratio and a larger value of R-squared in column (II). Though in both equations, consistent with the results in the previous studies, tariff margin has a significantly positive coefficient, it is difficult to compare our estimates quantitatively with those obtained in previous studies. The above is because of the qualitative differences in dependent variables. There are qualitative and quantitative differences in coefficients in the ROO dummy between columns (I) and (II). After controlling the Mills ratio, all coefficients for ROO dummy variables turn out to be insignificant. In the sense that the results differ depending on the inclusion of the Mills ratio, it is important to take into account the selection process of FTA products. 
Table 6. Estimation results of ECFA utilization

\begin{tabular}{|c|c|c|c|c|}
\hline & \multicolumn{2}{|c|}{$\begin{array}{l}\text { Ordinary Least } \\
\text { Squares }\end{array}$} & \multicolumn{2}{|c|}{$\begin{array}{c}\text { Poisson Pseudo } \\
\text { Maximum Likelihood }\end{array}$} \\
\hline & (I) & (II) & (III) & (IV) \\
\hline $\ln (M F N(t)-E C F A(t))$ & $\begin{array}{c}0.613 * * * \\
{[0.164]}\end{array}$ & $\begin{array}{c}0.535 * * * \\
{[0.158]}\end{array}$ & $\begin{array}{l}1.622 * * \\
{[0.652]}\end{array}$ & $\begin{array}{l}1.614 * * \\
{[0.707]}\end{array}$ \\
\hline \multicolumn{5}{|l|}{ ROO Dummy (Basis: WO) } \\
\hline $\mathrm{CH} / \mathrm{RVCL}$ & $\begin{array}{c}0.231 \\
{[0.763]}\end{array}$ & $\begin{array}{l}-0.518 \\
{[0.854]}\end{array}$ & $\begin{array}{c}0.229 \\
{[1.029]}\end{array}$ & $\begin{array}{c}-0.347 \\
{[1.182]}\end{array}$ \\
\hline $\mathrm{CH} / \mathrm{RVCH}$ & $\begin{array}{c}0.265 \\
{[0.646]}\end{array}$ & $\begin{array}{l}-1.129 \\
{[0.819]}\end{array}$ & $\begin{array}{c}-1.224 * \\
{[0.744]}\end{array}$ & $\begin{array}{c}-2.307^{*} * \\
{[1.119]}\end{array}$ \\
\hline $\mathrm{CH}$ & $\begin{array}{c}-0.196 \\
{[0.629]}\end{array}$ & $\begin{array}{l}-0.973 \\
{[0.747]}\end{array}$ & $\begin{array}{c}-0.685 \\
{[0.732]}\end{array}$ & $\begin{array}{c}-1.309 \\
{[0.964]}\end{array}$ \\
\hline$C C$ & $\begin{array}{c}1.112^{*} \\
{[0.568]}\end{array}$ & $\begin{array}{c}0.289 \\
{[0.705]}\end{array}$ & $\begin{array}{l}1.233^{* *} \\
{[0.625]}\end{array}$ & $\begin{array}{c}0.615 \\
{[0.807]}\end{array}$ \\
\hline $\mathrm{RVCH}$ & $\begin{array}{c}-0.198 \\
{[0.774]}\end{array}$ & $\begin{array}{l}-1.052 \\
{[0.883]}\end{array}$ & $\begin{array}{c}-0.609 \\
{[0.977]}\end{array}$ & $\begin{array}{c}-1.329 \\
{[1.204]}\end{array}$ \\
\hline$C S \& R V C H$ & $\begin{array}{c}-0.484 \\
{[0.762]}\end{array}$ & $\begin{array}{c}-1.29 \\
{[0.821]}\end{array}$ & $\begin{array}{c}-1.124 \\
{[1.159]}\end{array}$ & $\begin{array}{c}-2.309 \\
{[1.621]}\end{array}$ \\
\hline$C H \& R V C L$ & $\begin{array}{c}-0.263 \\
{[0.683]}\end{array}$ & $\begin{array}{l}-1.185 \\
{[0.790]}\end{array}$ & $\begin{array}{c}-1.907 * * \\
{[0.872]}\end{array}$ & $\begin{array}{c}-3.158 * * \\
{[1.370]}\end{array}$ \\
\hline$C H \& R V C H$ & $\begin{array}{c}0.194 \\
{[0.671]}\end{array}$ & $\begin{array}{l}-0.578 \\
{[0.769]}\end{array}$ & $\begin{array}{c}-0.780 \\
{[0.773]}\end{array}$ & $\begin{array}{c}-1.649 \\
{[1.092]}\end{array}$ \\
\hline$C C \& R V C L$ & $\begin{array}{l}1.509^{* *} \\
{[0.613]}\end{array}$ & $\begin{array}{c}0.727 \\
{[0.740]}\end{array}$ & $\begin{array}{c}-0.243 \\
{[0.794]}\end{array}$ & $\begin{array}{c}-0.820 \\
{[0.976]}\end{array}$ \\
\hline Mills ratio & & $\begin{array}{c}0.958 * * * \\
{[0.301]}\end{array}$ & & $\begin{array}{c}0.579 * \\
{[0.328]} \\
\end{array}$ \\
\hline Number of observations & 381 & 381 & 423 & 423 \\
\hline $\mathrm{R}^{2}$ & 0.3431 & 0.3821 & 0.4583 & 0.5549 \\
\hline Pseudo log-likelihood & & & -0.0869 & -0.0865 \\
\hline
\end{tabular}

(Notes) (i) CS, CH, and CC are the ROO criteria of Change in Subheading, Change in Heading, and Change in Chapter, respectively. WO indicates the Wholly obtained criterion. RVCL and RVCH are the ROO criteria for the less than $40 \%$ real value-added and the greater than $40 \%$ real value-added, respectively.

(ii) The dependent variable is the number of COOs issued divided by exports.

(iii) The parentheses are robust standard errors. ***, **, and * show $1 \%, 5 \%$, and $10 \%$ significance, respectively.

(iv) The Mills ratio is obtained from the probit estimation, for which results are reported in column (II) in Table 5.

(v) Industry dummy variables are included in all estimations. 
Our variable FTA Users ${ }_{p}$ ranges from zero to positive infinity, and thus we cannot take its $\log$ in the case of a zero-valued FTA Users. In order to naturally include such observations in our sample, Equation (2) is estimated by the Poisson Pseudo Maximum Likelihood (PPML) technique. The PPML method does not take log of the dependent variable and thus enables us to include observations with a zero-valued FTA Users ${ }_{p}$ in the estimation sample. Such a combination of sample selection and Poisson regression was proposed by Greene (1994). The results of Poisson regression are reported in columns (III) and (IV). Again, consistent with the findings in the previous studies, a larger tariff margin encourages greater use of FTA schemes. In contrast to those of the OLS regression, however, we found significant coefficients for some ROO variables. The most restrictive rule is $\mathrm{CH} \& \mathrm{RVCL}$, followed by $\mathrm{CH} / \mathrm{RVCH}$. The other types of ROO have statistically the same level of restrictiveness as WO. These results for ROO are inconsistent with our expectation that AND-type rules of origin decrease the FTA utilization more than OR-type rules. As a result, one possible interpretation is that ECFA ROOs are determined specific to products.

Our last robustness check is devoted to our definition of the dependent variable. Unlike that of the previous studies, the numerator of our dependent variable is the number of COOs issued, not exports under the FTA scheme. ${ }^{16}$ Since that number can be seen as a proxy for the number of exporters using the FTA scheme, the larger the exports per firm in an industry, the more likely our measure of FTA users would underestimate the FTA utilization compared with its measure used in the previous studies. In other words, the underestimation is more serious in industries where there are a larger number of productive firms, since the more productive firms export more (Melitz 2003). In order to account for this underestimation, we control for global industrial competitiveness by introducing the lagged Taiwanese RCA, which is also included in the selection equation. The extent of our underestimation will appear as a negative coefficient for this variable. The estimation results are reported in Table 7. The PPML estimation shows insignificant coefficients for the Taiwanese RCA. Thus, it may be possible to say that the underestimation in our measure of FTA users is not so serious particularly by including industry fixed effects. The other variables have qualitatively the same results as in Table 6.

\footnotetext{
${ }^{15}$ It is difficult to compare our results in ROOs with those obtained in previous studies, because ROOs in the FTAs or GSP programs analyzed in previous studies have much fewer varieties. For example, ROOs in the U.S. GSP program include only $35 \%$ of the real value added criterion.

${ }^{16}$ The definition of FTA utilization rates is different even among previous studies. Some studies define as a share of trade values under FTA schemes in the total trade values or in the trade values of products with a positive tariff margin. The share of the number of FTA users in total firms is also used.
} 
Table 7. Estimation results of ECFA utilization: Controlling Taiwanese RCA

\begin{tabular}{|c|c|c|c|c|}
\hline & $\underset{\mathrm{Sq}}{\text { Ordin }}$ & $\begin{array}{l}\text { Least } \\
\text { es }\end{array}$ & $\begin{array}{r}\text { Poiss } \\
\text { Maximu }\end{array}$ & $\begin{array}{l}\text { seudo } \\
\text { ikelihood }\end{array}$ \\
\hline & (I) & (II) & (III) & (IV) \\
\hline $\ln (M F N(t)-E C F A(t))$ & $\begin{array}{c}0.616^{* * *} \\
{[0.162]}\end{array}$ & $\begin{array}{c}0.545^{* * *} * \\
{[0.158]}\end{array}$ & $\begin{array}{l}1.623 * * \\
{[0.650]}\end{array}$ & $\begin{array}{l}1.611 * * \\
{[0.703]}\end{array}$ \\
\hline ROO Dummy (Basis: WO & & & & \\
\hline $\mathrm{CH} / \mathrm{RVCL}$ & $\begin{array}{c}0.295 \\
{[0.780]}\end{array}$ & $\begin{array}{c}-0.406 \\
{[0.855]}\end{array}$ & $\begin{array}{c}0.123 \\
{[1.040]}\end{array}$ & $\begin{array}{c}-0.564 \\
{[1.263]}\end{array}$ \\
\hline $\mathrm{CH} / \mathrm{RVCH}$ & $\begin{array}{c}0.253 \\
{[0.654]}\end{array}$ & $\begin{array}{c}-0.984 \\
{[0.818]}\end{array}$ & $\begin{array}{l}-1.215 \\
{[0.747]}\end{array}$ & $\begin{array}{c}-2.336^{* *} \\
{[1.132]}\end{array}$ \\
\hline $\mathrm{CH}$ & $\begin{array}{c}-0.205 \\
{[0.636]}\end{array}$ & $\begin{array}{c}-0.894 \\
{[0.738]}\end{array}$ & $\begin{array}{c}-0.677 \\
{[0.733]}\end{array}$ & $\begin{array}{c}-1.322 \\
{[0.968]}\end{array}$ \\
\hline$C C$ & $\begin{array}{c}1.115^{*} \\
{[0.579]}\end{array}$ & $\begin{array}{c}0.379 \\
{[0.696]}\end{array}$ & $\begin{array}{l}1.235^{* *} \\
{[0.624]}\end{array}$ & $\begin{array}{c}0.585 \\
{[0.817]}\end{array}$ \\
\hline $\mathrm{RVCH}$ & $\begin{array}{c}0.212 \\
{[1.004]}\end{array}$ & $\begin{array}{c}-0.761 \\
{[0.983]}\end{array}$ & $\begin{array}{c}-0.744 \\
{[0.881]}\end{array}$ & $\begin{array}{c}-1.614 \\
{[1.201]}\end{array}$ \\
\hline$C S \& R V C H$ & $\begin{array}{c}-0.441 \\
{[0.759]}\end{array}$ & $\begin{array}{l}-1.182 \\
{[0.815]}\end{array}$ & $\begin{array}{c}-1.109 \\
{[1.156]}\end{array}$ & $\begin{array}{c}-2.318 \\
{[1.624]}\end{array}$ \\
\hline$C H \& R V C L$ & $\begin{array}{c}-0.173 \\
{[0.692]}\end{array}$ & $\begin{array}{c}-1.042 \\
{[0.788]}\end{array}$ & $\begin{array}{c}-1.902 * * \\
{[0.873]}\end{array}$ & $\begin{array}{c}-3.177 * * \\
{[1.371]}\end{array}$ \\
\hline$C H \& R V C H$ & $\begin{array}{c}0.241 \\
{[0.674]}\end{array}$ & $\begin{array}{l}-0.472 \\
{[0.761]}\end{array}$ & $\begin{array}{l}-0.783 \\
{[0.772]}\end{array}$ & $\begin{array}{c}-1.679 \\
{[1.102]}\end{array}$ \\
\hline$C C \& R V C L$ & $\begin{array}{l}1.307^{* *} \\
{[0.626]}\end{array}$ & $\begin{array}{c}0.713 \\
{[0.727]}\end{array}$ & $\begin{array}{c}-0.179 \\
{[0.829]}\end{array}$ & $\begin{array}{c}-0.743 \\
{[0.983]}\end{array}$ \\
\hline Taiwanese RCA $(t-1)$ & $\begin{array}{c}-0.055 * * * \\
{[0.017]}\end{array}$ & $\begin{array}{c}-0.027 \\
{[0.018]}\end{array}$ & $\begin{array}{c}0.018 \\
{[0.036]}\end{array}$ & $\begin{array}{c}0.031 \\
{[0.036]}\end{array}$ \\
\hline Mills ratio & & $\begin{array}{c}0.854 * * * \\
{[0.315]}\end{array}$ & & $\begin{array}{l}0.603 * \\
{[0.342]} \\
\end{array}$ \\
\hline Number of observations & 381 & 381 & 423 & 423 \\
\hline $\mathrm{R}^{2}$ & 0.3581 & 0.3852 & 0.4704 & 0.5786 \\
\hline Pseudo log-likelihood & & & -0.0869 & -0.0865 \\
\hline
\end{tabular}

(Notes) (i) CS, CH, and CC are the ROO criteria of Change in Subheading, Change in Heading, and Change in Chapter, respectively. WO indicates the Wholly obtained criterion. RVCL and RVCH are the ROO criteria for the less than $40 \%$ real value-added and the greater than $40 \%$ real value-added, respectively.

(ii) The dependent variable is the number of COOs issued divided by exports.

(iii) The parentheses are robust standard errors. ***, **, and * show $1 \%, 5 \%$, and $10 \%$ significance, respectively.

(iv) The Mills ratio is obtained from the probit estimation, for which results are reported in column (II) in Table 5.

(v) Industry dummy variables are included in all estimations. 


\section{Concluding Remarks}

In this paper, we conducted an empirical investigation of the determinants of ECFA utilization in exports from Taiwan to China. To do this, we first estimated the selection equation for the kinds of products that obtained FTA preferential treatment, since products with FTA preferential rates are systematically chosen. As a result, we found that Taiwan includes products with a medium magnitude of benefits from tariff removal in the early harvest list, but does not succeed in including products with a large magnitude of benefits. Further, the products that have already been traded in substantial amounts are more likely to be included. We then estimated the equation for the determinants of FTA utilization by introducing an inverse of the Mills ratio, estimated in the selection equation. The findings are that, as expected, the FTA rates are more likely to be utilized for products with a larger tariff margin. Moreover, the most restrictive rule in terms of discouraging FTA utilization is Change in Healing \& RVCL, followed by Change in Healing/RVCH. This economically inconsistent result for Rules Of Origins might indicate that The Economic Cooperation Framework Agreement Rules Of Origins are determined in a product-specific manner.

Received 25 May 2013, Revised 20 March 2014, Accepted 10 October 2014

\section{References}

Ball, David S. "United States Effective Tariffs and Labor's Share." Journal of Political Economy 75 (1967): 183-87. Accessed May 21, 2011. URL: http://www.jstor.org/ stable/1829827.

Bombardini, Matilde. "Firm Heterogeneity and Lobby Participation." Journal of International Economics 75 (2008): 329-48. Accessed April 9, 2011. doi: 10.1016/ j.jinteco.2008.03.003.

Bureau, Jean-Christophe, Raja Chakir, and Jacques Gallezot. "The Utilisation of Trade Preferences for Developing Countries in the Agri-food Sector." Journal of Agricultural 
Economics 58 (2007): 175-98. Accessed May 21, 2011. doi: 10.1111/j.1477-9552.2007. 00097.x.

Cadot, Olivier, and Jaime de Melo. "Why OECD Countries Should Reform Rules of Origin." World Bank Research Observer 23 (2007): 77-105. Accessed October 4, 2011. doi: 10.1093/wbro/lkm010.

Cadot, Olivier, Jaime de Melo, and Marcelo Olarreaga. "Lobbying and the Structure of Protection." CEPR Discussion Paper 1574. Centre for Economic Policy Research, London (1997). Accessed May 21, 2011. URL: http://dev3.cepr.org/pubs/new-dps/dplist. asp?dpno=1574.

Cadot, Oliver, Celine Carrere, Jaime de Melo, and Bolormaa Tumurchudur. "Productspecific Rules of Origin in EU and US Preferential Trading Arrangements: An Assessment." World Trade Review 5 (2006): 199-224. Accessed May 16, 2011. doi: http://dx.doi.org/10.1017/S1474745606002758.

Caves, Richard E. "Economic Models of Political Choice: Canada's Tariff Structure." Canadian Journal of Economics 9 (1976): 278-300. Accessed May 21, 2011. doi: 10.2307/134522. URL: http://www.jstor.org/stable/134522.

Chen, Shin-Horng, Meng-Chun Liu, and Pei-Chang Wen. "The ECFA and Its Effect on Cross-strait Trade and Investment: A Taiwanese Perspective." China Economic Journal 4 (2011): 105-24. Accessed June 13, 2012. doi:10.1080/17538963.2011.666060.

Chen, Kun-Ming, Meng-Chia Tsai, Chia-Ching Lin, and Chaw-Hsia Tu. "Impact of Cross-Strait Trade Liberalization: A Computable General Equilibrium Analysis." China \& World Economy 17 (2009): 106-22. Accessed November 13, 2011. doi: 10.1111/ j.1749-124X.2009.01176.x.

Demidova, Svetlana, and Kala Krishna. "Firm Heterogeneity and Firm Behavior with Conditional Policies." Economics Letters 98 (2008): 122-8. Accessed August 17, 2011. doi: 10.1016/j.econlet.2007.04.020.

Dent, Christopher M. "Taiwan and the New East Asian Regionalism.” Issues \& Studies 45 (2009): 144-55. Accessed May 21, 2011. URL: http://140.119.170.21/attachments/ journal /add/107-158.pdf.

Estevadeordal, Antoni, Caroline Freund, and Emannuel Ornelas. "Does Regionalism Affect Trade Liberalization toward NonMembers?" Quarterly Journal of Economics 123 
(2008): 1531-75. Accessed May 21, 2011. doi: 10.1162/qjec.2008.123.4.1531.

Francois, Joseph, Bernard Hoekman, and Miriam Manchin. "Preference Erosion and Multilateral Trade Liberalization." World Bank Economic Review 20 (2006): 197-216. Accessed May 22, 2011. doi: 10.1093/wber/lhj010.

Gawande, Kishore, Prarin Krishna, and Michael J. Robbins. "Foreign Lobbies and U.S. Trade Policy." Review of Economics and Statistics 88 (2006): 563-71. Accessed October 4, 2011. doi:10.1162/rest.88.3.563.

Greene, William H. "Accounting for Excess Zeros and Sample Selection in Poisson and Negative Binomial Regression Models.” Working Papers 94-10 (1994):1-37. New York University, Leonard N. Stern School of Business, Department of Economics. Accessed May 21, 2011. URL: http://hdl.handle.net/2451/26263.

Grossman, Gene M, and Elhanan Helpman. "Protection for Sale." American Economic Review 84 (1994): 833-50. Accessed May 21, 2011. URL: http://links.jstor.org/ sici?sici=0002-8282\%28199409\%2984\%3A4\%3C833\%3APFS\%3E2.0.CO\%3B2-Y.

Grossman, Gene M, and Elhanan Helpman. "The Politics of Free-Trade Agreements." American Economic Review 85 (1995): 667-90. Accessed May 21, 2011. URL: http:// www.jstor.org/stable/2118226.

Hakobyan, Shushanik. "Accounting for Underutilization of Trade Preference Programs: U.S. Generalized System of Preferences." University of Virginia, 2010. Accessed May 21, 2011. URL: http://usitc.gov/research_and_analysis/documents/Hakobyan_abstract. pdf.

Hayakawa, Kazunobu. "Measuring Fixed Costs for Firms' Use of a Free Trade Agreement: Threshold Regression Approach.” Economics Letters 113 (2011): 301-3. Accessed September 2, 2011. doi: 10.1016/j.econlet.2011.08.026.

Hillman, Arye L. "Declining Industries and Political-Support Protectionist Motives." American Economic Review 72 (1982): 1180-7. Accessed May 21, 2011. URL: http:// www.jstor.org/stable/1812033.

Hong, Tsai-Lung, and Chih-Hai Yang. "The Economic Cooperation Framework Agreement between China and Taiwan: Understanding Its Economics and Politics." Asian Economic Paper 10 (2011): 79-96. Accessed September 20, 2011. doi:10.1162/ ASEP_a_00104. 
Levy, Philip I. "A Political Economy Analysis of Free Trade Agreements." American Economic Review 87 (1997): 506-19. Accessed May 21, 2011. URL: http://www.jstor. org/stable/2951361.

Manchin, Miriam. "Preference Utilisation and Tariff Reduction in EU Imports from ACP Countries." The World Economy 29 (2006): 1243-66. Accessed September 8, 2011. doi: 10.1111/j.1467-9701.2006.00838.x.

Mayer, Wolfgang. "Endogenous Tariff Formation." American Economic Review 74 (1984): 970-85. Accessed May 21, 2011. URL: http://www.jstor.org/stable/556.

Melitz, Marc J. "The Impact of Trade on Intra-Industry Reallocations and Aggregate Industry Productivity." Econometrica 71 (2003): 1695-725. Accessed October 24, 2011. doi: 10.1111/1468-0262.00467.

Mitra, Devashish. "Endogenous Lobby Formation and Endogenous Protection: A LongRun Model of Trade Policy Determination.” American Economic Review 89 (1999): 1116-34. Accessed May 21, 2011. URL: http://www.jstor.org/stable/117050.

Olarreaga, Marcelo, and Isidro Soloaga. "Endogenous Tariff Formation: The Case of Mercosur." World Bank Economic Review 12 (1998): 297-320. Accessed May 21, 2011. doi: 10.1093/wber/12.2.297.

Pincus, Jonathan J. "Pressure Groups and the Pattern of Tariffs." Journal of Political Economy 83 (1975): 757-78. Accessed May 21, 2011. URL: http:/www.jstor.org/ stable/1830398.

Stigler, George J. "The Theory of Economic Regulation." Bell Journal of Economics and Management Science 2 (1971): 3-21. Accessed May 21, 2011. URL: http://www. jstor.org/stable/3003160. 